\title{
Genetic background influences embryonic lethality and the occurrence of neural tube defects in Men1 null mice: relevance to genetic modifiers
}

\author{
Manuel C Lemos, Brian Harding, Anita A C Reed, Jeshmi Jeyabalan, Gerard V Walls, \\ Michael R Bowl, James Sharpe ${ }^{1}$, Sarah Wedden', Julie E Moss², Allyson Ross², \\ Duncan Davidson ${ }^{2}$ and Rajesh V Thakker \\ Academic Endocrine Unit, Nuffield Department of Clinical Medicine, Oxford Centre for Diabetes, Endocrinology and Metabolism, Churchill Hospital, \\ University of Oxford, Headington, Oxford OX3 7LJ, UK \\ ${ }^{1} \mathrm{MRC}$ Technology, Crewe Road South, Edinburgh EH4 2SP, UK \\ ${ }^{2}$ MRC Human Genetics Unit, Western General Hospital, Crewe Road, Edinburgh EH4 2XU, UK \\ (Correspondence should be addressed to R V Thakker; Email: rajesh.thakker@ndm.ox.ac.uk)
}

\begin{abstract}
Germline mutations of the multiple endocrine neoplasia type 1 (MEN1) gene cause parathyroid, pancreatic and pituitary tumours in man. MEN1 mutations also cause familial isolated primary hyperparathyroidism (FIHP) and the same MEN1 mutations, in different families, can cause either FIHP or MEN1. This suggests a role for genetic background and modifier genes in altering the expression of a mutation. We investigated the effects of genetic background on the phenotype of embryonic lethality that occurs in a mouse model for MEN1. Men $1^{+/-}$mice were backcrossed to generate C57BL/6 and 129S6/SvEv incipient congenic strains, and used to obtain homozygous $M e n 1^{-/-}$mice. No viable $\mathrm{Men} 1^{-1-}$ mice were obtained. The analysis of 411 live embryos obtained at $9 \cdot 5-16 \cdot 5$ days post-coitum (dpc) revealed that significant deviations from the expected Mendelian 1:2:1 genotype ratio were first observed at 12.5
\end{abstract}

and $14.5 \mathrm{dpc}$ in the $129 \mathrm{~S} 6 / \mathrm{SvEv}$ and $\mathrm{C} 57 \mathrm{BL} / 6$ strains respectively $(P<0 \cdot 05)$. Moreover, live $M e n 1^{-/-}$embryos were absent by 13.5 and $15.5 \mathrm{dpc}$ in the $129 \mathrm{~S} 6 / \mathrm{SvEv}$ and C57BL/6 strains respectively thereby indicating an earlier lethality by 2 days in the $129 \mathrm{~S} 6 / \mathrm{SvEv}$ strain $(P<0 \cdot 01)$. Men $1^{-/-}$embryos had macroscopic haemorrhages, and histology and optical projection tomography revealed them to have internal haemorrhages, myocardial hypotrophy, pericardial effusion, hepatic abnormalities and neural tube defects. The neural tube defects occurred exclusively in 129S6/SvEv embryos (21 vs 0\%, $P<0 \cdot 01$ ). Thus, our findings demonstrate the importance of genetic background in influencing the phenotypes of embryonic lethality and neural tube defects in $\mathrm{Men} 1^{-1-}$ mice, and implicate a role for genetic modifiers.

Journal of Endocrinology (2009) 203, 133-142

\section{Introduction}

Multiple endocrine neoplasia type 1 (MEN1) is an autosomal dominant disorder characterised, in man, by the combined occurrence of tumours of the parathyroids, pancreatic islets and anterior pituitary (Thakker 2006). Some patients may also develop adrenal cortical tumours, carcinoid tumours, facial angiofibromas, collagenomas and lipomas. The MEN1 gene, which in man is located on chromosome 11q13 and encodes a 610 amino acid protein (menin), belongs to the class of tumour suppressors (Chandrasekharappa et al. 1997, Lemmens et al. 1997). Menin, which is ubiquitously expressed and is predominantly a nuclear protein, has been shown to interact with a number of proteins that are involved in transcriptional regulation, DNA replication and cell cycle control (Balogh et al. 2006). These interacting proteins include a member of the activating protein-1 (AP-1) transcription factor complex, JunD; placenta and embryonic expression gene product (Pem); mothers against decapentaplegic homolog 3 (Smad3) and major components of nuclear factor- $\mathrm{KB}$ (Agarwal et al. 1999, Balogh et al. 2006, Lemos \& Thakker 2008). Over 1000 MEN1 germline mutations, which are scattered throughout the $>9 \mathrm{~kb}$ genomic sequence, have been reported (Lemos \& Thakker 2008). The majority ( $>70 \%)$ of these mutations are predicted to lead to truncated forms of menin, although there appears to be an absence of genotype-phenotype correlation (Lemos \& Thakker 2008). More than 97\% of these MEN1 germline mutations are associated with the multiple development of tumours associated with this syndrome. However, the remaining $<3 \%$ are associated with the sole occurrence of parathyroid tumours, a condition referred to as familial isolated primary hyperparathyroidism (FIHP; Hannan 
et al. 2008, Lemos \& Thakker 2008). The 30 MEN1 mutations reported in patients with FIHP are remarkably similar to those reported in patients with MEN1, and 15 (i.e. $50 \%$ ) of these MEN1 mutations have been reported to occur in both FIHP and MEN1 patients (Table 1; Hannan et al. 2008, Lemos \& Thakker 2008). Thus, the same MEN1 mutation can, in different families, cause MEN1 or FIHP and the mechanisms that determine this altered phenotypic expression remain to be elucidated. One mechanism that may influence phenotype modification is the influence of genetic background due to modifier genes (Nadeau 2003a). The effects of such modifier genes and genetic background are difficult to study in man because of the late onset of the disorder and because of the effects of allelic heterogeneity and environmental factors that cannot be readily controlled (Nadeau 2005). However, these variables can be controlled in studies of inbred laboratory mice, which may also develop the disease phenotype within a shorter duration (Nadeau 2001). Indeed, genetic modifiers have been shown, mainly by such studies in mice, to affect penetrance, dominance, modification, expressivity and pleiotrophy (Nadeau 2001, 2003b). We therefore embarked on studying the effects of genetic background on the phenotypic expression of MEN1 in a mouse model that was generated by deleting exons 1 and 2 (Fig. 1A), which contains the ATG translation start signal (Lemos et al. 2007). Mice deleted for one allele, i.e. heterozygotes $\left(\mathrm{Men} 1^{+/-}\right)$develop parathyroid, pancreatic islet cell, anterior pituitary and adrenal cortical tumours after the age of 12 months (Lemos et al. 2007), and this is similar to that reported in other MEN1 mouse models (Crabtree et al. 2001, Bertolino et al. 2003b, Loffler et al. 2007). Moreover, mice deleted for both alleles, i.e. homozygotes $\left(\operatorname{Men} 1^{-/-}\right)$,

Table 1 Multiple endocrine neoplasia type 1 (MEN1) mutations reported in both familial isolated primary hyperparathyroidism (FIHP) and the MEN1 syndrome

Exon

Mutation type $\mathrm{a}^{\mathrm{a}}$

Intragenic deletion

2

3

Intragenic insertion

4

\section{Missense}

5

6

7

8

9

Nonsense

10

Splice-site

11

12

13

14

Gross gene deletion

15

10

10

3

4

4

4

9

10
Codon

83-84

363

Boundary between exon 3 and intron 3

Boundary between intron 4 and exon 5

Boundary between exon 5 and intron 5

Boundary between exon 9 and intron 9
527

559

516

153

225

255

260

418

218

Nucleotide $784-9^{d}$

Nucleotide $824+1^{\text {d }}$

Nucleotide $1350+1^{\mathrm{d}}$
Predicted effect

Frameshift

In-frame deletion of Glu363

Frameshift

Frameshift

Asp153Val

Gly225Arg

Glu255Lys

Gln260Pro

Asp418His

Stop signal at codon 527

Donor splice-site alteration

Acceptor splice-site alteration

Donor splice-site alteration

Donor splice-site alteration

Gross deletion

\section{References}

Chandrasekharappa et al. (1997) and Karges et al. (2000)

Chandrasekharappa et al. (1997) and Miedlich et al. $(2001)^{\mathrm{C}}$

Asteria et al. $(2001)^{\mathrm{b}}$ and Cetani et al. $(2002)^{\mathrm{c}}$

Agarwal et al. (1997) ${ }^{\mathrm{b}}$ and Warner et al. (2004)

Pannett et al. (2003) ${ }^{\mathrm{C}}$ and Ellard et al. $(2005)^{\mathrm{b}}$

Hai et al. (1999) ${ }^{\mathrm{b}}$ and Mizusawa et al. (2006)

Teh et al. $(1998)^{\mathrm{C}}$ and Ellard et al. (2005)

Kassem et al. (2000) ${ }^{\mathrm{C}}$ and Jager et al. (2006)

Warner et al. (2004) ${ }^{\mathrm{C}}$ and Jap et al. (2005)

Chandrasekharappa et al. (1997) ${ }^{\mathrm{b}}$ and Perrier et al. (2002)

Giraud et al. (1998) $)^{\mathrm{b}}$ and Dwarakanathan et al. $(2000)^{\mathrm{c}}$

Turner et al. (2002) ${ }^{\mathrm{b}}$ and Cetani et al. $(2006)^{\mathrm{c}}$

Crepin et al. $(2003)^{b}$ and Cetani et al. (2006) ${ }^{\mathrm{C}}$

Carrasco et al. $(2004)^{\mathrm{C}}$ and Ellard et al. $(2005)^{\mathrm{b}}$

Cavaco et al. (2002) $)^{\mathrm{b}}$ and Cebrian et al. $(2003)^{\mathrm{c}}$

\footnotetext{
${ }^{a}$ Mutation number.

${ }^{\mathrm{b}}$ Reference describing presence of mutation in MEN1 patient.

${ }^{\mathrm{C}}$ Reference describing presence of mutation in FIHP patient.

${ }^{d}$ Nucleotide positions start from the initiation codon and are based on the cDNA reference sequence (GenBank accession number NM_130799.1).
} 


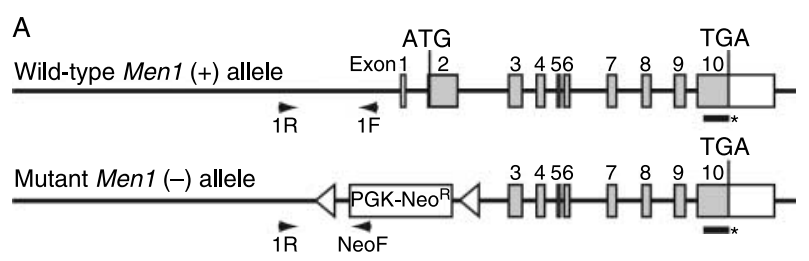

B
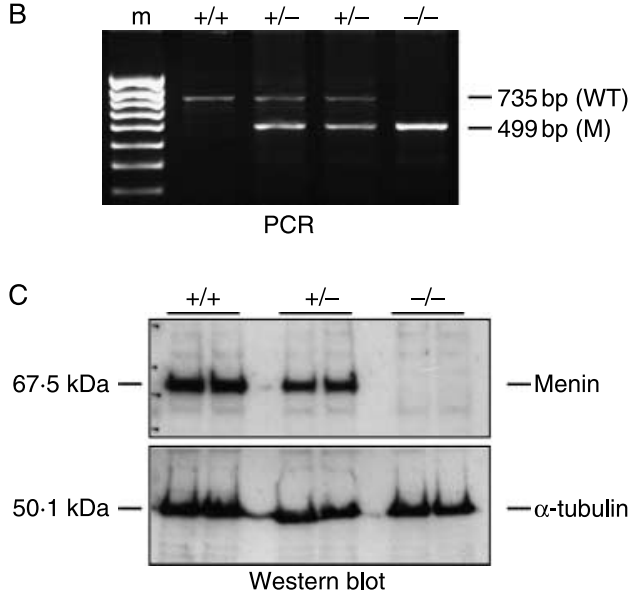

Figure 1 Genotyping and menin expression in embryos. Embryos were obtained from Men $1^{+/-}$intercrosses. (A) Men $1^{+/-}$mice had one target allele in which exons 1 and 2 of the Men 1 gene had been replaced by a PGK-Neo ${ }^{R}$ cassette (Lemos et al. 2007). This targeted disruption would result in a loss of the initiation codon, ATG, in exon 2 and hence a loss of menin expression, which is similar to the situation in man where the majority $(>70 \%$ ) of patients have mutations that lead to truncated forms of menin. The location of the epitope (amino acids 571-611, in exon 10) against which the rabbit polyclonal anti-menin antibody has been raised is indicated by the solid horizontal black bar with an asterisk. Thus, use of this antibody would detect only full-length menin, but not the truncated forms. Primers $1 \mathrm{R}$ and $1 \mathrm{~F}$, which were located in the $5^{\prime}$-UTR of the Men 1 gene, yielded a $735 \mathrm{bp}$ product from the wild-type (WT) allele. Use of primers $1 R$ and NeoF, which were specific for the Neomycin transferase gene, yielded a $499 \mathrm{bp}$ product from the mutant (M) allele. (B) PCR analysis for the genotyping of embryos was undertaken using PCR and Men 1 -specific primers (1R and $1 \mathrm{~F}$, or $1 \mathrm{R}$ and NeoF). A standard marker $(\mathrm{m})$, as a $100 \mathrm{bp}$ ladder is shown. (C) Western

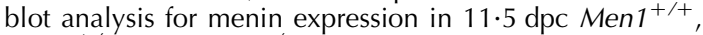
Men $1^{+/-}$and Men $1^{-1-}$ embryos demonstrating menin expression in Men $1^{+/+}$and Men $1^{+/-}$embryos, but its absence in Men $1^{-1-}$ embryos. An anti- $\alpha$-tubulin antibody was used as a control.

are embryonically lethal with abnormalities of the heart, liver, neural tube and cranio-facial bones (Crabtree et al. 2001, Bertolino et al. 2003a). Because of the late onset (over 12 months of age) of tumours in Men $1^{+/-}$mice, we decided to study the possible effects of genetic modifiers and background on the phenotype of embryonic lethality in $\mathrm{Men} 1^{-/-}$mice, as this would facilitate establishing the proof of principle of phenotypic modification by genetic background in MEN1. In order to pursue these studies, we established Men $1^{+/-}$ mice on two different genetic backgrounds that consisted of the C57BL/6 and 129S6/SvEv strains.

\section{Materials and Methods}

Generation of Men $1^{+/-}$mice incipient congenic strains

A mouse model for MEN1 (Lemos et al. 2007) that had a targeted disruption of exons 1 and 2, which contains the translation initiation codon ATG, was used (Fig. 1A). The loss of the initiation codon by the targeted disruption would result in a loss of menin expression, and hence have similarities to the situation in $>70 \%$ of MEN1 patients who have mutations that are predicted to lead to truncated forms of menin (Lemos \& Thakker 2008). Men $1^{+/-}$mice have been reported to develop parathyroid, pancreatic islet, anterior pituitary, adrenal cortical and gonadal tumours (Lemos et al. 2007). F1 Men $1^{+/-}$mice were mated to C57BL/6J and 129S6/SvEvTac inbred mice to initiate two lines of Men1 knockout mice on different genetic backgrounds. Heterozygotes were consecutively backcrossed to each of these strains for five to nine generations, to generate two different incipient congenic strains with 96.9-99.8\% genetic identity in either the C57BL/6 or the $129 \mathrm{~S} 6 / \mathrm{SvEv}$ inbred strains. Following this, heterozygote intercrosses were made to obtain homozygote mice. Mice were kept in accordance with UK Home Office welfare guidelines and project license restrictions.

\section{Genotyping of mice}

Genotypes of adult, neonatal and embryonic mice were determined by PCR analysis using DNA extracted from appropriate tissues (e.g. tails, auriclar biopsies or amniotic sacs) and Men 1 gene-specific primers, as reported (Lemos et al. 2007). Primers 1R (5'-CCA AAC TCC ATG TTC CAA TAT GAC AGC-3') and 1F (5'-CAC GAA GTC TGT AAT GAC CCT GTT TCC- $3^{\prime}$ ) yielded a 735 bp wild-type fragment and primers $1 \mathrm{R}$ and NeoF $\left(5^{\prime}\right.$-CTC TCG TGG GAT CAT TGT TTT TCT C-3') yielded a 499 bp fragment (Fig. 1A and B).

\section{Western blot analysis}

Total protein was extracted from $M e n 1^{+/+}, M e n 1^{+/-}$and Men $1^{-/-}$whole embryos that were 11.5 days post-coitum (dpc), and $20 \mu \mathrm{g}$ protein was separated by $10 \%$ SDS-PAGE electrophoresis, and electrotransferred to a nitrocellulose membrane (Nesbit et al. 2004). The primary antibodies used were rabbit polyclonal: anti-menin (1:1000; Bethyl Laboratories, Montgomery, TX, USA); anti-c-Jun (1:500; Abcam, Cambridge, UK); anti-JunB (1:500; Abcam); antiJunD (1:500; Abcam) and anti- $\boldsymbol{\alpha}$-tubulin (1:500; Abcam). The secondary antibody used was HRP-conjugated goat anti-rabbit (1:6000; Bio-Rad Laboratories) and was detected by utilising an enhanced chemiluminescence western blotting detection kit (Amersham Biosciences). 
Phenotype studies of embryos

Embryos from $M e n 1^{+/-}$intercrosses were removed by Caesarean section at successive days post-coitum following timed matings and the ages of the embryos were confirmed by assessing the development of external structures using the Theiler staging system (Theiler 1989; available online at http://genex.hgu.mrc.ac.uk/Atlas/Theiler_book_download. html). Amniotic sacs were collected for genotyping using PCR as described above. Embryos were inspected for overall external morphology, photographed and fixed in $4 \%$ paraformaldehyde. In order to characterise internal abnormalities, three-dimensional imaging by optical projection tomography (OPT) of the embryos was undertaken, using previously described methods (Sharpe et al. 2002). OPT is a technique that allows three-dimensional imaging of biological specimens and the analysis of virtual sections in any orientation. Thus, OPT has several advantages over other imaging techniques such as confocal microscopy, optical coherence tomography, microscopic magnetic resonance imaging or reconstruction of serial sections (Sharpe et al. 2002, Sharpe 2003). A total of 25 embryos $\left(5 \mathrm{Men}^{+/+}\right.$, $4 \mathrm{Men} 1^{+/-}$and $16 \mathrm{Men}^{-/-}$) aged $10 \cdot 5-13 \cdot 5 \mathrm{dpc}$ were analysed by OPT; 16 of the embryos were on a C57BL/6 background (four $\mathrm{Men} 1^{+/+}$, two $\mathrm{Men} 1^{+/-}$and ten Men $\left.1^{-/-}\right)$and nine were on a $129 \mathrm{~S} 6 / \mathrm{SvEv}$ background (one $\mathrm{Men} 1^{+/+}$, two $\mathrm{Men} 1^{+/-}$and six Men $1^{-/-}$). For histological examination, embryos were embedded in paraffin, and transverse sections $(5-7 \mu \mathrm{m}$ thickness) were obtained and stained with haematoxylin and eosin (Wang et al. 2008). Immunostaining for menin expression was performed using a menin antibody (rabbit anti-menin, Abcam), as follows. Wax sections for immunohistochemistry were transferred to electrostatically charged slides (Superfrost Plus, Menzel Glaser, Leuven, Belgium), de-paraffinised in xylene substitute and rehydrated via graded ethanol. Antigen retrieval was performed in citrate buffer, $\mathrm{pH} 6$, in an autoclave, followed by treatment with $3 \%$ aqueous hydrogen peroxide for $30 \mathrm{~min}$. After blocking with serum for $30 \mathrm{~min}$, sections were incubated with menin antibody $(1: 500)$ at $4{ }^{\circ} \mathrm{C}$, overnight. HRP-labelled goat anti-rabbit polymer system (EnVision + System-HRP (DAB), Dako UK Ltd, Ely, UK) was used to develop the specific signals.

\section{Statistical analysis}

The proportion of live Men $1^{-/-}$embryos at each gestational age was compared with the theoretically expected Mendelian proportion $(25 \%)$ by performing the $\chi^{2}$ goodness-of-fit test $\left(\chi_{\text {G.O.F. }}^{2}\right)$ with one degree of freedom and the results expressed as two-tailed $P$ values. The proportion of live Men $1^{-/-}$ embryos at each age was also compared between the two different genetic backgrounds by performing Fisher's exact test, and the threshold for statistical significance was set at $P<0 \cdot 05$.

\section{Results}

Men $1^{+/-}$mice, established on the C57BL/6 or $129 \mathrm{~S} 6 / \mathrm{SvEv}$ strains, were intercrossed. The genotypes of the offspring (Table 2; newborn and embryos) were determined by the use of PCR and Men1-specific primers (Fig. 1B) and the expression of menin in $M e n 1^{+/+}$and $M e n 1^{+/-}$, and its absence in $M e n 1^{-1-}$ embryos demonstrated by western blot analysis (Fig. 1C). The absence of $M e n 1^{-/-}$mice among 44 newborn offspring, demonstrated that Men $1^{-/-}$mice from this model for MEN1, generated by a targeted disruption of exons 1 and 2 (Fig. 1A), are embryonically lethal. This finding of embryonic lethality is similar to that previously published from other MEN1 mouse models, which have reported that lethality commences at about $12.5 \mathrm{dpc}$ (Crabtree et al. 2001, Bertolino et al. 2003a). Men $1^{+/-}$embryos were viable without an increased mortality and had normal development,

Table 2 Multiple endocrine neoplasia type 1 (Men1) genotype analysis of 499 mice obtained from Men $1^{+/-}$intercrosses on two different genetic backgrounds. A $\chi^{2}$ goodness-of-fit ( $\chi$ G.O.F.2) test with one degree of freedom was used to compare the observed proportions of live homozygous mutant offspring $(-/-)$ with the expected Mendelian proportion $(25 \%)$ and the results were expressed as two-tailed $P$ values. Significant deviations from the expected frequency of live Men $1^{-/-}$embryos were observed from $12 \cdot 5$ days post-coitus (dpc) on the $129 \mathrm{~S} 6 / \mathrm{SvEv}$ background and from day $14.5 \mathrm{dpc}$ on the C57BL/ 6 background

C57BL/6 No. of live (dead) offspring

\begin{tabular}{|c|c|c|c|}
\hline $\mathrm{Men}^{+/+}$ & Men1 $^{+/-}$ & Men1 $1^{-/-}$ & $\chi_{\text {G.O.F. }}^{2}$ \\
\hline
\end{tabular}

Age $(\mathrm{dpc})$

$9 \cdot 5$

$10 \cdot 5$

$11 \cdot 5$

$12 \cdot 5$

$13 \cdot 5$

$14 \cdot 5$

$15 \cdot 5$

$16 \cdot 5$

Newborn

$3(0)$
$1(0)$
$14(0)$
$16(1)$
$13(0)$
$8(0)$
$13(0)$
$4(0)$
7

$$
2(0)
$$

$25(0)$

$35(0)$

$15(1)$

$12(0)$

$17(0)$

$3(0)$

13
129S6/SvEv No. of live (dead) offspring

\begin{tabular}{|c|c|c|c|}
\hline $\mathrm{Men}^{+/+}$ & Men $^{+/-}$ & Men1 ${ }^{-/-}$ & $\chi_{\text {G.O.F. }}^{2}$ \\
\hline $15(0)$ & $24(1)$ & $11(0)$ & $P=\mathrm{NS}$ \\
\hline $6(0)$ & $13(1)$ & $6(1)$ & $P=\mathrm{NS}$ \\
\hline $12(1)$ & $17(3)$ & $2(2)$ & $P=0 \cdot 02$ \\
\hline $20(0)$ & $32(1)$ & $0(8)$ & $P<0.0001$ \\
\hline $0(1)$ & $8(0)$ & $0(2)$ & \\
\hline $4(0)$ & $11(0)$ & $0(6)$ & \\
\hline $2(0)$ & $2(0)$ & $0(0)$ & \\
\hline 7 & 17 & 0 & $P=0.005$ \\
\hline
\end{tabular}

NS, not significant. 
indicating that haploinsufficiency of Men1 is unlikely to affect normal embryogenesis. In order to search for the effects of genetic background on the embryonic lethality, analysis of embryos (total $=499$ embryos; 411 alive and 88 dead) at different stages of development $(9 \cdot 5-16 \cdot 5 \mathrm{dpc})$, from the two different incipient congenic strains was undertaken (Table 2). All Men $1^{-/}$embryos were alive up to $10.5 \mathrm{dpc}$ in both strains and the expected Mendelian ratio of 1:2:1 for Men $1^{+/+}:$Men $1^{+/-}:$Men $1^{-/-}$for live embryos obtained from $M e n 1^{+/-}$intercrosses was observed (Table 2). After $10 \cdot 5 \mathrm{dpc}$, dead Men $1^{-/-}$embryos were observed with increasing frequency such that at later gestational stages $(12.5 \mathrm{dpc}$ in the $129 \mathrm{~S} 6 / \mathrm{SvEv}$ strain and $14.5 \mathrm{dpc}$ in the C57BL/6 strain), there was a significant deviation from the expected Mendelian ratio, which would result in $25 \%$ of Men $1^{-/-}$live embryos (Table 2 and Fig. 2). In addition, survival of $\operatorname{Men} 1^{-/-}$embryos was significantly reduced by 2 days in the 129S6/SvEv strain when compared with those in the C57BL/6 strain (Table 2 and Fig. 2). These results demonstrate that genetic background, and hence likely genetic modifiers, influences the phenotype of embryonic lethality in $M e n 1^{-/-}$mice.

The causes of the embryonic lethality in both strains were investigated by macroscopic examination for external abnormalities, OPT for internal abnormalities, and by histology (Table 3). Macroscopic examination in 58 live Men $1^{-/-}$embryos (39 on the C57BL/6 and 19 on the

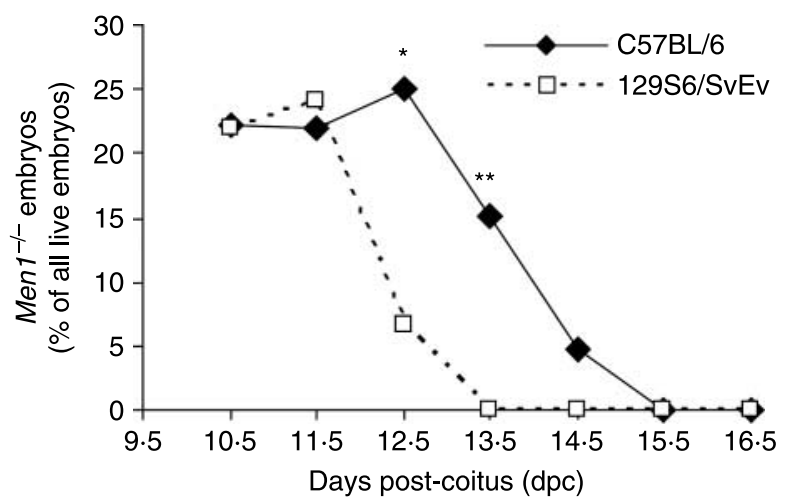

Figure 2 Survival of $M e n 1^{-/-}$embryos on two different genetic backgrounds. The proportion of Men1 $1^{-1}$ live embryos from the total number (i.e. Men $1^{+/+}+$Men $1^{+/-}+M e n 1^{-/-}$) at each gestational stage is shown. The expected Mendelian ratio from the Men $1^{+/-}$intercrosses of Men $1^{+/+}:$Men $1^{+/-}:$Men $1^{-/-}$offspring is $1: 2: 1$ yielding an expected proportion of $25 \%$ for Men $1^{-/}$ embryos. In 129S6/SvEv Men1 mice, this expected proportion was observed at 10.5 and $11.5 \mathrm{dpc}$, but was significantly lower, at $6.5 \%$, by $\geq 12.5 \mathrm{dpc}$. In contrast, in the C $57 \mathrm{BL} / 6$ strain, the expected proportion was observed at $10 \cdot 5,11.5$ and $12.5 \mathrm{dpc}$, but was significantly lower at $15 \cdot 2 \%$, by $\geq 13 \cdot 5 \mathrm{dpc}$. Furthermore, there were no surviving Men $1^{-1-}$ embryos at $13.5 \mathrm{dpc}$ in the $129 \mathrm{~S} 6 / \mathrm{SvEv}$ strain and at $15 \cdot 5 \mathrm{dpc}$ in the C57BL/ 6 strain. A comparison of the survival of the Men $1^{-1-}$ embryos in the two strains revealed that, at 12.5 and $13.5 \mathrm{dpc}$, significantly fewer Men $1^{-/-}$embryos survived in the 129 S6/SvEv strain ${ }^{*} P=0 \cdot 031$, $* * P=0 \cdot 004$, Fisher's exact test).
Table 3 Abnormalities in Men $1^{-/-}$live embryos on the C57BL/6 $(n=39)$ and $129 \mathrm{~S} 6 / \mathrm{SvEv}(n=19)$ backgrounds

\begin{tabular}{ll} 
Background \\
\hline $\mathrm{C} 57 \mathrm{BL} / 6^{\mathrm{a}}$ & $129 \mathrm{~S} 6 / \mathrm{SvEv}^{\mathrm{a}}$ \\
\hline
\end{tabular}

\begin{tabular}{|c|c|c|}
\hline \multicolumn{3}{|l|}{ Abnormalities } \\
\hline Developmental delay & $+(4 / 39)$ & $+(2 / 19)$ \\
\hline Haemorrhage & $+(1 / 39)$ & $+(4 / 19)^{*}$ \\
\hline Myocardial hypotrophy ${ }^{b}$ & $+(9 / 10)$ & $+(4 / 6)$ \\
\hline Pericardial effusion ${ }^{b}$ & $+(9 / 10)$ & $+(4 / 6)$ \\
\hline Oedema & $+(4 / 39)$ & $-(0 / 19)^{\dagger}$ \\
\hline Liver size decreased $^{b}$ & $+(9 / 10)$ & $+(3 / 6)$ \\
\hline Neural tube defect & $-(0 / 39)$ & $+(4 / 19)^{+}$ \\
\hline Embryonic lethality by $\mathrm{dpc}$ & $14 \cdot 5$ & $12 \cdot 5$ \\
\hline
\end{tabular}

${ }^{*} P<0 \cdot 05,{ }^{\dagger} P<0 \cdot 01$; Fisher's exact test.

${ }^{\mathrm{a}}+$, Presence; - , absence of abnormality. Men $1^{-/-}$embryos with the abnormality are represented as the numerator and the total of Men $1^{-1-}$ embryos examined are represented as the denominator in the fractions shown in parenthesis.

${ }^{\mathrm{b}}$ Based on OPT analysis of a subset of $16 \mathrm{Men}^{-1-}$ embryos (ten on the C57BL/6 and six on the 129S6/SvEv background).

129S6/SvEv background) revealed that 67\% $(n=39)$ did not have external abnormalities and that only $33 \%(n=19)$ had abnormalities that included delayed development (DD), haemorrhages (HA), neural tube defects (NT) in the form of exencephaly and abnormal fluid accumulation (oedema, OE) along the dorsal region (Fig. 3); among the Men $1^{-/-}$ embryos on the C57BL/6 background, $23 \%(n=9)$ had such external abnormalities, while among those on the 129S6/ SvEv background, $52 \%(n=10)$ had these external abnormalities (Table 3 ). The Men $1^{-1-}$ embryos also had internal haemorrhages (Fig. 3G-I). In order to investigate further for internal structural abnormalities that may contribute to embryonic lethality phenotype, $\operatorname{Men} 1^{-/-}, \operatorname{Men} 1^{+/-}$and control Men $1^{+/+}$embryos, aged from $10 \cdot 5$ to $13 \cdot 5 \mathrm{dpc}$, were studied by OPT. The 16 Men $1^{-/-}$embryos included those that were externally normal ( $n=6$, three on the C57BL/6 and three on the $129 \mathrm{~S} 6 / \mathrm{SvEv}$ background) and those with visible malformations $(n=10$, seven on the C57BL/ 6 and three on the $129 \mathrm{~S} 6 / \mathrm{SvEv}$ background), and ranged in age from $10 \cdot 5$ to $13 \cdot 5 \mathrm{dpc}$. Eleven of the $16 \mathrm{Men} 1^{-/-}$embryos (nine on the C57BL/6 and two on the $129 \mathrm{~S} 6 / \mathrm{SvEv}$ background) had myocardial hypotrophy $(\mathrm{MH})$, pericardial effusion (PE) and a reduction in liver size (LS); two Men $1^{-/-}$ embryos (both on the 129S6/SvEv background) had MH and $\mathrm{PE}$; one Men $1^{-/-}$embryo, which was on the $129 \mathrm{~S} 6 / \mathrm{SvEv}$ background, had only LS and two Men $1^{-/-}$embryos had none of these internal abnormalities, one of these being on the C57BL/6 with OE, and the other being on the 129S6/ SvEv background with a NT. Eight of the ten Men $1^{-/-}$ embryos with external abnormalities also had internal abnormalities and these occurred with the following associations: DD occurred in with $\mathrm{MH}, \mathrm{PE}$ and $\mathrm{LS}$ in four Men $1^{-/-}$embryos on the C57BL/6 background, one of which also had HA, and in association with $\mathrm{MH}$ and $\mathrm{PE}$ in one Men $1^{-/-}$embryo on the $129 \mathrm{~S} 6 / \mathrm{SvEv}$ background; OE 

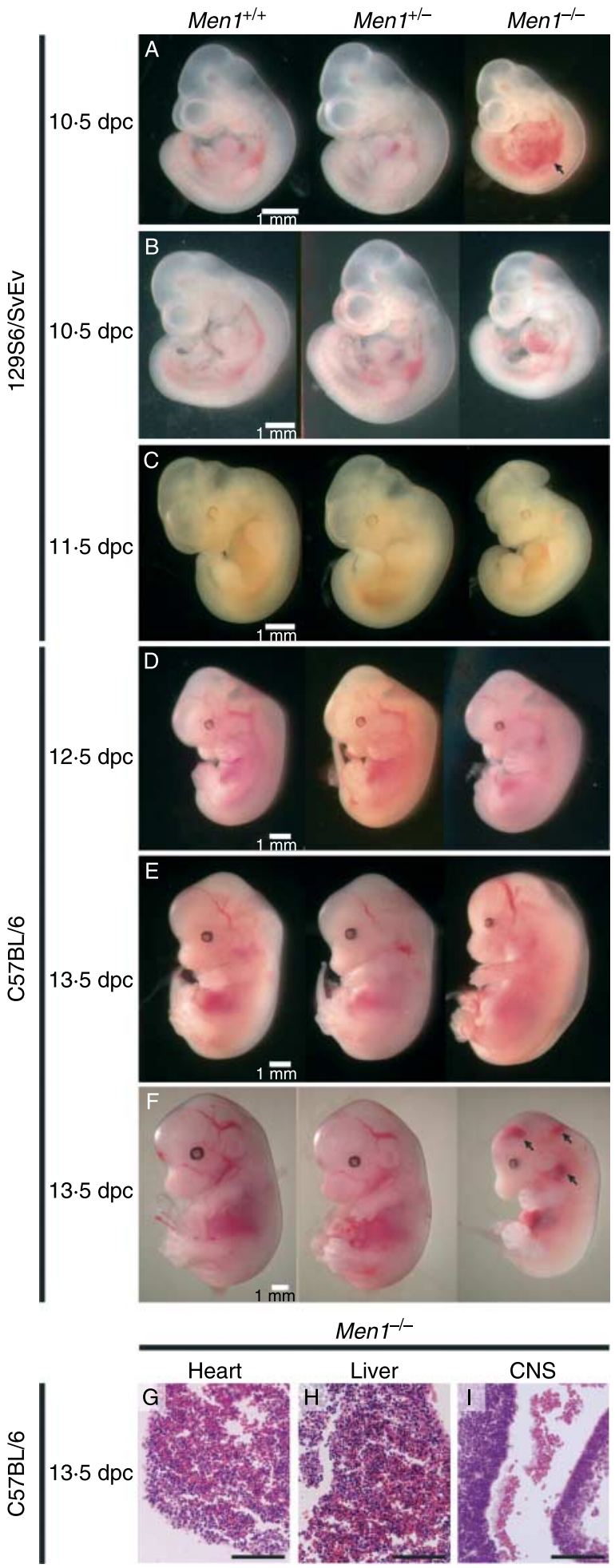

occurred with $\mathrm{MH}, \mathrm{PE}$ and LS in two Men $1^{-/-}$embryos on the C57BL/6 background; NT occurred with $\mathrm{MH}, \mathrm{PE}$ and LS in one Men $1^{-/-}$embryo on the $129 \mathrm{~S} 6 / \mathrm{SvEv}$ background. All Men1 ${ }^{-/-}$embryos with normal external morphology (three on the C57BL/6 and three on the 129S6/SvEv background) were found, by OPT, to have internal structural abnormalities that included $\mathrm{MH}, \mathrm{PE}$ and LS (Fig. 4); all the three Men $1^{-/-}$embryos on the C57BL/6 background had $\mathrm{MH}, \mathrm{PE}$ and LS; and among the three Men $1^{-/-}$embryos on the 129S6/SvEv background, one had $\mathrm{MH}, \mathrm{PE}$ and LS, one had MH and PE, and one had LS only. These abnormalities were confirmed by histological analysis of transverse sections obtained from the same embryos that had been studied by OPT. These histology studies revealed a thin myocardium with sparse trabeculation and also a reduced cell density in the liver with the presence of large intercellular spaces (Fig. 5). Immunostaining using an anti-menin antibody demonstrated menin expression in the nuclei of the cardiac cells and hepatocytes of the Men $1^{+/+}$embryos, but a loss of menin expression in the Men $1^{-/-}$embryos (Fig. 5).

These cardiac and hepatic abnormalities (Figs 4 and 5) have similarities to those reported to occur in embryos lacking the AP-1 family member c-Jun (Hilberg et al. 1993, Eferl et al. 1999). Moreover, menin has been reported to interact with another AP-1 family member, JunD (Agarwal et al. 1999), and homozygous deletion of JunD results in apparently normal mouse embryos, with only adult mutant males showing mild phenotypic features that consisted of impaired growth, hormone imbalance and age-dependent defects in reproduction due to impaired spermatogenesis (Jochum et al. 2001). We therefore investigated different members of the AP-1 family, such as c-Jun, JunD and JunB, for altered expression by using western blot analysis and protein extracts obtained from $\operatorname{Men} 1^{+/+}, \operatorname{Men} 1^{+/-}$and Men1 $1^{-/-} 11.5 \mathrm{dpc}$ embryos from

Figure 3 Embryos obtained from Men $1^{+/-}$intercrosses. Embryos obtained (A-C) on the 129S6/SvEv and (D-F) C57BL/6 backgrounds, and at the different gestational ages of (A and B) $10.5 \mathrm{dpc}$, (C) $11.5 \mathrm{dpc}$, (D) $12.5 \mathrm{dpc}$ and (E and F) $13.5 \mathrm{dpc}$, are shown. Men $1^{+/+}$and Men $1^{+/-}$embryos appeared normal and were similar in size at all gestational ages in both the 129S6/SvEv and C57BL/6 strains. Men $1^{-/-}$embryos on the $129 S 6 / S v E v$ background were normal up to $9.5 \mathrm{dpc}$ but were smaller, presumably due to developmental delay, and showed abnormalities from $10.5 \mathrm{dpc}$, which were associated with death by $13 \cdot 5 \mathrm{dpc}$ (Fig. 2). Men $1^{-1-}$ embryos on the C57BL/ 6 background were normal up to $11.5 \mathrm{dpc}$, but showed abnormalities from $12.5 \mathrm{dpc}$, which were associated with death by $15 \cdot 5 \mathrm{dpc}$ (Fig. 2). The range of abnormalities in the Men $1^{-1-}$ embryos is represented: (A) macroscopic haemorrhages (arrow) in thoraco-abdominal region; (B) developmental delay; (C) exencephaly and developmental delay; (D) absence of external malformations; (E) oedema with fluid accumulation along the dorsal region; and $(\mathrm{F})$ macroscopic haemorrhages (arrows) in the head, thoracic and abdominal regions. (A-F) Scale bars $(1 \mathrm{~mm})$. (G-l) Histological analysis using H\&E sections obtained from the $13 \cdot 5 \mathrm{dpc}$ Men $1^{-/-}$embryo, which is shown on the right hand panel of $(\mathrm{F})$, and is on the $\mathrm{C} 57 \mathrm{BL} / 6$ background, to illustrate internal haemorrhages in the $(\mathrm{G})$ heart, $(\mathrm{H})$ liver and $(\mathrm{I})$ central nervous system (CNS). (G-l) Scale bars $(0 \cdot 1 \mathrm{~mm})$. 

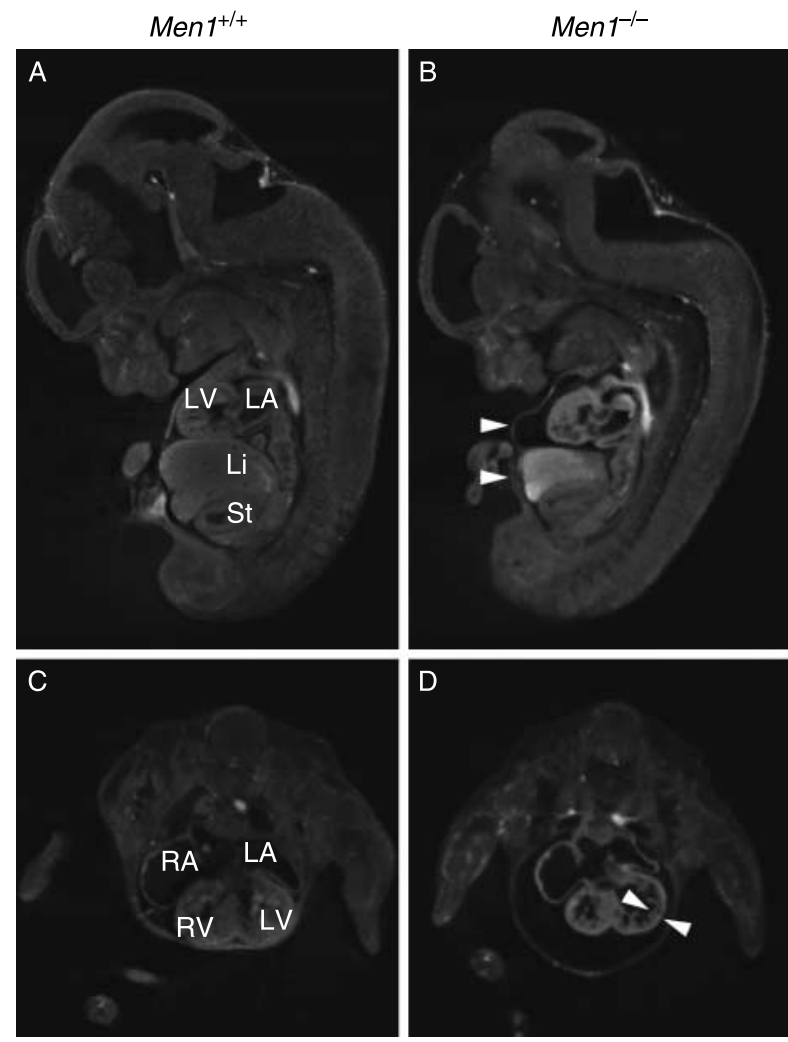

Figure 4 Optical projection tomography (OPT) scans obtained from Men $1^{+/+}$and Men $1^{-1-}$ embryos on the C57BL/ 6 background at $12.5 \mathrm{dpc}$. In the Men $1^{-/-}$embryo, a markedly smaller liver and pericardial effusion (arrowheads, B) were observed. Transverse thoracic sections confirmed the occurrence of the pericardial effusion in the Men $1^{-1-}$ embryos and also showed a reduced thickness of the myocardium (arrowheads, D). LV, left ventricle; RV, right ventricle; LA, left atrium; RA, right atrium; $\mathrm{Li}$, liver; St, stomach.

the 129S6/SvEv and C57BL/6 backgrounds. The expression of c-Jun, JunD and JunB in the Men $1^{-1-}$ embryos was similar to that observed in the $\mathrm{Men} 1^{+/-}$and $\mathrm{Men} 1^{+/+}$ embryos (data not shown), thereby indicating that the cardiac and hepatic abnormalities observed in the Men $1^{-/}$embryos (Figs 4 and 5) are likely to arise without involvement of these AP-1 family members.

The abnormalities observed in the $M e n 1^{-/-}$embryos (Figs 3 and 5 and Table 3) from our Men 1 model are similar to those reported in other MEN1 mouse models, in which Men $1^{-/-}$mice died between 11.5 and $13.5 \mathrm{dpc}$ with growth retardation and defects in the nervous system, heart and liver (Crabtree et al. 2001, Bertolino et al. 2003a). However, these other studies investigated Men $1^{-/-}$embryos on a $129 / \mathrm{Sv}$ or mixed background and therefore could not assess the effects of genetic background. Our studies show that although some of the structural abnormalities (e.g. DD) are similar in the 129S6/SvEv and C57BL/6 genetic backgrounds (Table 3), there are nevertheless important differences; these relate to the neural tube defects (Fig. 3C) and OE (Fig. 3E). The neural tube defects were found only in $129 \mathrm{~S} 6 / \mathrm{SvEv} \mathrm{Men} 1^{-/-}$ embryos and not in C57BL/6 Men $1^{-/-}$embryos (21 vs $0 \%$, Fisher's exact test $P=0 \cdot 009$; Table 3 ). OE with fluid accumulation along the dorsal region (Fig. 3E) was only found in $M e n 1^{-1-}$ embryos aged $13.5 \mathrm{dpc}$ or older and hence this was limited to the C57BL/6 strain, as $129 \mathrm{~S} 6 / \mathrm{SvEv}$ embryos did not survive beyond $12.5 \mathrm{dpc}$. These results are consistent with a role for genetic background, and hence likely genetic modifiers, influencing neural tube development in $M e n 1^{-/-}$mice.
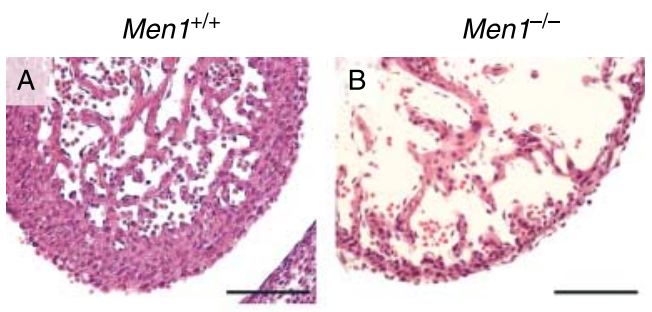

Heart
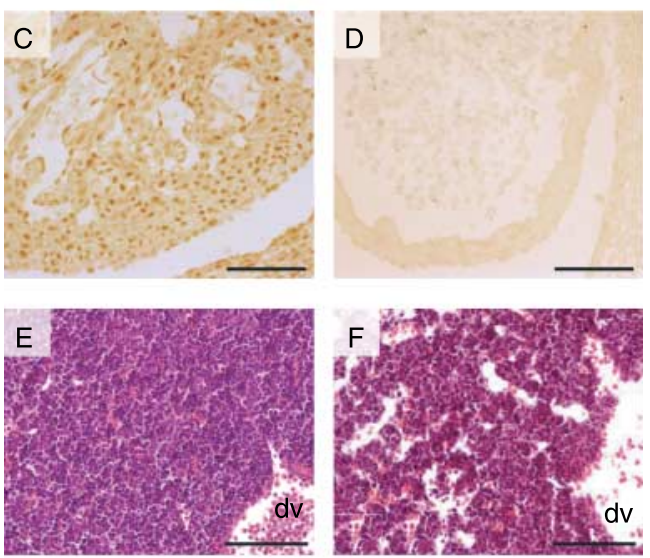

Liver

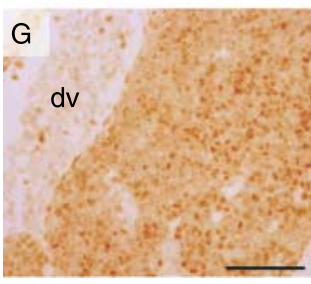

$\mathrm{H}$

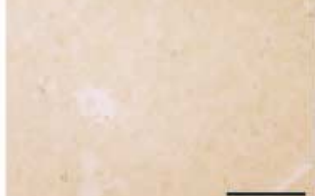

Figure 5 Pathological changes detected by $H \& E$ and menin immunostaining of sections of the heart and liver. Men $1^{+/+}$and Men $1^{-/-}$embryos, on the C57BL/6 background, at $12.5 \mathrm{dpc}$ were studied. (A) Transverse section from Men $1^{+1+}$ embryo revealed a normal left ventricular morphology but (B) in an Men1 ${ }^{-1-}$ embryo, the ventricular wall is significantly thinner and the density of the trabeculae is lower. (C) Men $1^{+/+}$embryos expressed menin in the nuclei of myocardial cells, whereas (D) Men ${ }^{-}$embryos had a loss of menin expression in all cells. (E) Transverse section from Men $1^{+1+}$ embryo revealed normal hepatic architecture, but (F) in Men $1^{-/-}$embryos, the liver had decreased cellularity with the presence of large intercellular spaces. (G) Men $1^{+/+}$embryos expressed menin in the nuclei of hepatocytes, whereas $(H)$ Men $1^{-/-}$embryos had a loss of menin expression in all cells. $\mathrm{dv}$, ductus venosus. Scale bar $=0 \cdot 1 \mathrm{~mm}$. 


\section{Discussion}

Our results, which demonstrate that genetic background is an important determinant of the phenotypes of the stage of embryonic lethality (Table 2 and Fig. 2) and of neural tube defects (Fig. 3) in Men $1^{-/-}$mouse embryos, are consistent with a role for genetic modifiers influencing the expression of the MEN1 phenotype. Thus, these results help to establish the proof of principle of phenotypic modification by genetic background in MEN1. The influence of genetic background on neural tube closure defects resulting from the targeted disruption of other genes (e.g. p53, Cart1, p300, Casp3, Ski and $\mathrm{Nog}$ ) has been previously reported and the decreased frequency of neural tube defects on the C57 background when compared with the 129-related background observed (Armstrong et al. 1995, Sah et al. 1995, Zhao et al. 1996, Yao et al. 1998, Colmenares et al. 2002, Leonard et al. 2002, Stottmann et al. 2006, Harris \& Juriloff 2007). Thus, our findings are in agreement with these previous reports and support the occurrence of different genetic modifiers between the C57 and 129-related strains.

The observed reduction in LS in the Men $1^{-/-}$embryos (Fig. 4) in our study differs from the reported absence of hepatic abnormalities in adult conditional Men1 knockout mice that had a homozygous deletion of the Men 1 gene in the liver (Scacheri et al. 2004). One possible explanation is that the loss of both Men 1 alleles in the Men $1^{-/-}$embryos may result in metabolic abnormalities such as hypoxia, which may be secondary to the observed cardiac abnormalities of $\mathrm{MH}$ and PE (Figs 4 and 5), and that such extra-hepatic metabolic abnormalities may contribute to the decrease in LS. Likewise, the cardiac abnormalities of $\mathrm{MH}$ and PE may be secondary to hypoxia or other such metabolic alterations that may primarily arise at extra-cardiac sites.

The finding of PE (Fig. 4) in the Men $1^{-/-}$embryos has not been previously reported. It seems likely that the $\mathrm{MH}$ (Fig. 5) is contributing to cardiac failure and the observed $\mathrm{OE}$ (Fig. 3), which has previously been reported (Crabtree et al. 2001, Bertolino et al. 2003a), and to the PE (Fig. 4). It is likely that the other Men $1^{-1-}$ mice from the other models also develop PE, but this may not have been detected by the histological methods; this illustrates the value of OPT in revealing additional aspects of mutant morphology. Indeed, this is similar to the situation reported in the asplenic phenotype of Bapx1 null mice in which OPT was able to reveal the presence of abnormal ventral surfaces of grooves and ridges in mutant stomachs that may have been missed because of artefacts induced by mounting the sections onto glass slides (Sharpe et al. 2002). The application of OPT to study endocrine glands in embryos and adults promises to be useful, particularly as it can enable three-dimensional imaging to be undertaken, as is illustrated by a recent study of intact adult mouse pancreas that performed cellular and molecular assessments to investigate autoimmune insulitis in type 1 diabetes mellitus (Alanentalo et al. 2008).
In summary, our study, which has demonstrated the effects of genetic background on the phenotypes of embryonic lethality and neural tube defects in Men $1^{-1-}$ mice, helps to establish the proof of principle that genetic modifiers may influence the expression of the Men 1 mutation in mice. This has relevance for studies in mice and man, as it opens the way for longer-term studies aimed at elucidating the basis of endocrine tumour development in different glands, and the mechanisms determining the development of FIHP and MEN1 in patients with MEN1 mutations. Indeed, modifier genes discovered in mice have often been relevant to the study of human diseases, such as cystic fibrosis, and familial adenomatous polyposis (Nadeau 2001, 2003b). Mouse embryonic lethality associated with null mutations of several genes has been shown to be strain dependent and this has allowed the mapping of modifier loci, as was the case for the Tgf $\beta 1$ and $p 53$ knockout mice (Bonyadi et al. 1997, Evans et al. 2004). Genetic modifiers of Men 1 remain to be identified but their identification could provide a better understanding of the function of menin and its molecular interactions in mammalian development and in endocrine tumourigenesis.

\section{Declaration of interest}

The authors declare that there is no conflict of interest that could be perceived as prejudicing the impartiality of the research reported.

\section{Funding}

This work was supported by the Medical Research Council (grant number G9825289, 2004) and the Portuguese Foundation for Science and Technology (BD/12415/2003) to M C L.

\section{Acknowledgements}

We are grateful for support to the Medical Research Council, UK (M C L, B H, A A C R, J J, G V W, J S, S W, J E M, A R, D D, R V T) and to Mrs Tracey Walker for typing the manuscript.

\section{References}

Agarwal SK, Kester MB, Debelenko LV, Heppner C, Emmert-Buck MR, Skarulis MC, Doppman JL, Kim YS, Lubensky IA, Zhuang Z et al. 1997 Germline mutations of the MEN1 gene in familial multiple endocrine neoplasia type 1 and related states. Human Molecular Genetics 6 1169-1175.

Agarwal SK, Guru SC, Heppner C, Erdos MR, Collins RM, Park SY, Saggar S, Chandrasekharappa SC, Collins FS, Spiegel AM et al. 1999 Menin interacts with the AP1 transcription factor JunD and represses JunDactivated transcription. Cell 96 143-152.

Alanentalo T, Loren CE, Larefalk A, Sharpe J, Holmberg D \& Ahlgren U 2008 High-resolution three-dimensional imaging of islet-infiltrate interactions based on optical projection tomography assessments of the intact adult mouse pancreas. Journal of Biomedical Optics 13054070.

Armstrong JF, Kaufman MH, Harrison DJ \& Clarke AR 1995 Highfrequency developmental abnormalities in p53-deficient mice. Current Biology 5 931-936. 
Asteria C, Faglia G, Roncoroni R, Borretta G, Ribotto P \& Beck-Peccoz P 2001 Identification of three novel menin mutations (c.741delGTCA, c. $1348 \mathrm{~T}>$ C, c.1785delA) in unrelated Italian families affected with multiple endocrine neoplasia type 1: additional information for mutational screening. Human Mutation 17237.

Balogh K, Racz K, Patocs A \& Hunyady L 2006 Menin and its interacting proteins: elucidation of menin function. Trends in Endocrinology and Metabolism 17 357-364.

Bertolino P, Radovanovic I, Casse H, Aguzzi A, Wang ZQ \& Zhang CX $2003 a$ Genetic ablation of the tumor suppressor menin causes lethality at mid-gestation with defects in multiple organs. Mechanisms of Development $120549-560$.

Bertolino P, Tong WM, Galendo D, Wang ZQ \& Zhang CX 2003 b Heterozygous Men1 mutant mice develop a range of endocrine tumors mimicking multiple endocrine neoplasia type 1. Molecular Endocrinology 17 1880-1892.

Bonyadi M, Rusholme SA, Cousins FM, Su HC, Biron CA, Farrall M \& Akhurst RJ 1997 Mapping of a major genetic modifier of embryonic lethality in TGF beta 1 knockout mice. Nature Genetics 15 207-211.

Carrasco CA, Gonzalez AA, Carvajal CA, Campusano C, Oestreicher E, Arteaga E, Wohllk N \& Fardella CE 2004 Novel intronic mutation of MEN1 gene causing familial isolated primary hyperparathyroidism. Journal of Clinical Endocrinology and Metabolism 89 4124-4129.

Cavaco BM, Domingues R, Bacelar MC, Cardoso H, Barros L, Gomes L, Ruas MM, Agapito A, Garrao A, Pannett AA et al. 2002 Mutational analysis of Portuguese families with multiple endocrine neoplasia type 1 reveals large germline deletions. Clinical Endocrinology 56 465-473.

Cebrian A, Ruiz-Llorente S, Cascon A, Pollan M, Diez JJ, Pico A, Telleria D, Benitez J \& Robledo M 2003 Mutational and gross deletion study of the MEN1 gene and correlation with clinical features in Spanish patients. Journal of Medical Genetics 40 e72.

Cetani F, Pardi E, Giovannetti A, Vignali E, Borsari S, Golia F, Cianferotti L, Viacava P, Miccoli P, Gasperi M et al. 2002 Genetic analysis of the MEN1 gene and HPRT2 locus in two Italian kindreds with familial isolated hyperparathyroidism. Clinical Endocrinology 56 457-464.

Cetani F, Pardi E, Ambrogini E, Lemmi M, Borsari S, Cianferotti L, Vignali E, Viacava P, Berti P, Mariotti S et al. 2006 Genetic analyses in familial isolated hyperparathyroidism: implication for clinical assessment and surgical management. Clinical Endocrinology 64 146-152.

Chandrasekharappa SC, Guru SC, Manickam P, Olufemi SE, Collins FS, Emmert-Buck MR, Debelenko LV, Zhuang Z, Lubensky IA, Liotta LA et al. 1997 Positional cloning of the gene for multiple endocrine neoplasiatype 1. Science 276 404-407.

Colmenares C, Heilstedt HA, Shaffer LG, Schwartz S, Berk M, Murray JC \& Stavnezer E 2002 Loss of the SKI proto-oncogene in individuals affected with 1 p36 deletion syndrome is predicted by strain-dependent defects in Ski-/ - mice. Nature Genetics 30 106-109.

Crabtree JS, Scacheri PC, Ward JM, Garrett-Beal L, Emmert-Buck MR, Edgemon KA, Lorang D, Libutti SK, Chandrasekharappa SC, Marx SJ et al. 2001 A mouse model of multiple endocrine neoplasia, type 1, develops multiple endocrine tumors. PNAS 98 1118-1123.

Crepin M, Escande F, Pigny P, Buisine MP, Calender A, Porchet N \& Odou MF 2003 Efficient mutation detection in MEN1 gene using a combination of single-strand conformation polymorphism (MDGA) and heteroduplex analysis. Electrophoresis 24 26-33.

Dwarakanathan AA, Zwart S \& Oathus RC 2000 Isolated familial hyperparathyroidism with a novel mutation of the MEN1 gene. Endocrine Practice 6 268-270.

Eferl R, Sibilia M, Hilberg F, Fuchsbichler A, Kufferath I, Guertl B, Zenz R, Wagner EF \& Zatloukal K 1999 Functions of c-Jun in liver and heart development. Journal of Cell Biology 145 1049-1061.

Ellard S, Hattersley AT, Brewer CM \& Vaidya B 2005 Detection of an MEN1 gene mutation depends on clinical features and supports current referral criteria for diagnostic molecular genetic testing. Clinical Endocrinology 62 169-175.

Evans SC, Liang M, Amos C, Gu X \& Lozano G 2004 A novel genetic modifier of p53, mop1, results in embryonic lethality. Mammalian Genome 15 415-423.
Giraud S, Zhang CX, Serova-Sinilnikova O, Wautot V, Salandre J, Buisson N, Waterlot C, Bauters C, Porchet N, Aubert JP et al. 1998 Germ-line mutation analysis in patients with multiple endocrine neoplasia type 1 and related disorders. American Journal of Human Genetics 63 455-467.

Hai N, Aoki N, Matsuda A, Mori T \& Kosugi S 1999 Germline MEN1 mutations in sixteen Japanese families with multiple endocrine neoplasia type 1 (MEN1). European Journal of Endocrinology 141 475-480.

Hannan FM, Nesbit MA, Christie PT, Fratter C, Dudley NE, Sadler GP \& Thakker RV 2008 Familial isolated primary hyperparathyroidism caused by mutations of the MEN1 gene. Nature Clinical Practice. Endocrinology and Metabolism 4 53-58.

Harris MJ \& Juriloff DM 2007 Mouse mutants with neural tube closure defects and their role in understanding human neural tube defects. Birth Defects Research. Part A, Clinical and Molecular Teratology 79 187-210.

Hilberg F, Aguzzi A, Howells N \& Wagner EF 1993 c-jun is essential for normal mouse development and hepatogenesis. Nature 365 179-181.

Jager AC, Friis-Hansen L, Hansen TV, Eskildsen PC, Solling K, Knigge U, Hansen CP, Andersen PH, Brixen K, Feldt-Rasmussen U et al. 2006 Characteristics of the Danish families with multiple endocrine neoplasia type 1. Molecular and Cellular Endocrinology 249 123-132.

Jap TS, Chiu CY, Won JG, Wu YC \& Chen HS 2005 Novel mutations in the MEN1 gene in subjects with multiple endocrine neoplasia-1. Clinical Endocrinology 62 336-342.

Jochum W, Passegue E \& Wagner EF 2001 AP-1 in mouse development and tumorigenesis. Oncogene 20 2401-2412.

Karges W, Jostarndt K, Maier S, Flemming A, Weitz M, Wissmann A, Feldmann B, Dralle H, Wagner P \& Boehm BO 2000 Multiple endocrine neoplasia type 1 (MEN1) gene mutations in a subset of patients with sporadic and familial primary hyperparathyroidism target the coding sequence but spare the promoter region. Journal of Endocrinology 166 1-9.

Kassem M, Kruse TA, Wong FK, Larsson C \& Teh BT 2000 Familial isolated hyperparathyroidism as a variant of multiple endocrine neoplasia type 1 in a large Danish pedigree. Journal of Clinical Endocrinology and Metabolism 85 165-167.

Lemmens I, Van de Ven WJ, Kas K, Zhang CX, Giraud S, Wautot V, Buisson N, De Witte K, Salandre J, Lenoir G et al. 1997 Identification of the multiple endocrine neoplasia type 1 (MEN1) gene. The European Consortium on MEN1. Human Molecular Genetics 6 1177-1183.

Lemos MC \& Thakker RV 2008 Multiple endocrine neoplasia type 1 (MEN1): analysis of 1336 mutations reported in the first decade following identification of the gene. Human Mutation 29 22-32.

Lemos MC, Harding B, Bowl MR, Reed AAC, Tateossian H, Hough TA, Fraser W, Cheeseman MT \& Thakker RV 2007 Mice deleted for a multiple endocrine neoplasia type 1 (MEN1) allele develop pancreatic, pituitary and parathyroid tumours in association with hypercalcaemia. Endocrine Abstracts 13 OC22.

Leonard JR, Klocke BJ, D'Sa C, Flavell RA \& Roth KA 2002 Straindependent neurodevelopmental abnormalities in caspase-3-deficient mice. Journal of Neuropathology and Experimental Neurology 61 673-677.

Loffler KA, Biondi CA, Gartside M, Waring P, Stark M, Serewko-Auret MM, Muller HK, Hayward NK \& Kay GF 2007 Broad tumor spectrum in a mouse model of multiple endocrine neoplasia type 1. International Journal of Cancer 120 259-267.

Miedlich S, Lohmann T, Schneyer U, Lamesch P \& Paschke R 2001 Familial isolated primary hyperparathyroidism - a multiple endocrine neoplasia type 1 variant? European Journal of Endocrinology 145 155-160.

Mizusawa N, Uchino S, Iwata T, Tsuyuguchi M, Suzuki Y, Mizukoshi T, Yamashita Y, Sakurai A, Suzuki S, Beniko M et al. 2006 Genetic analyses in patients with familial isolated hyperparathyroidism and hyperparathyroidism-jaw tumour syndrome. Clinical Endocrinology 65 9-16.

Nadeau JH 2001 Modifier genes in mice and humans. Nature Reviews. Genetics 2 165-174.

Nadeau JH 2003a Genetics. Modifying the message. Science 301 927-928.

Nadeau JH 2003 b Modifier genes and protective alleles in humans and mice. Current Opinion in Genetics \& Development 13 290-295.

Nadeau JH 2005 Listening to genetic background noise. New England Journal of Medicine 352 1598-1599. 
Nesbit MA, Bowl MR, Harding B, Ali A, Ayala A, Crowe C, Dobbie A, Hampson G, Holdaway I, Levine MA et al. 2004 Characterization of GATA3 mutations in the hypoparathyroidism, deafness, and renal dysplasia (HDR) syndrome. Journal of Biological Chemistry 279 22624-22634.

Pannett AA, Kennedy AM, Turner JJ, Forbes SA, Cavaco BM, Bassett JH, Cianferotti L, Harding B, Shine B, Flinter F et al. 2003 Multiple endocrine neoplasia type 1 (MEN1) germline mutations in familial isolated primary hyperparathyroidism. Clinical Endocrinology 58 639-646.

Perrier ND, Villablanca A, Larsson C, Wong M, Ituarte P, Teh BT \& Clark OH 2002 Genetic screening for MEN1 mutations in families presenting with familial primary hyperparathyroidism. World Journal of Surgery 26 907-913.

Sah VP, Attardi LD, Mulligan GJ, Williams BO, Bronson RT \& Jacks T 1995 A subset of p53-deficient embryos exhibit exencephaly. Nature Genetics 10 175-180.

Scacheri PC, Crabtree JS, Kennedy AL, Swain GP, Ward JM, Marx SJ, Spiegel AM \& Collins FS 2004 Homozygous loss of menin is well tolerated in liver, a tissue not affected in MEN1. Mammalian Genome 15 872-877.

Sharpe J 2003 Optical projection tomography as a new tool for studying embryo anatomy. Journal of Anatomy 202 175-181.

Sharpe J, Ahlgren U, Perry P, Hill B, Ross A, Hecksher-Sorensen J, Baldock R \& Davidson D 2002 Optical projection tomography as a tool for 3D microscopy and gene expression studies. Science 296 541-545.

Stottmann RW, Berrong M, Matta K, Choi M \& Klingensmith J 2006 The BMP antagonist Noggin promotes cranial and spinal neurulation by distinct mechanisms. Developmental Biology 295 647-663.

Teh BT, Esapa CT, Houlston R, Grandell U, Farnebo F, Nordenskjold M, Pearce CJ, Carmichael D, Larsson C \& Harris PE 1998 A family with isolated hyperparathyroidism segregating a missense MEN1 mutation and showing loss of the wild-type alleles in the parathyroid tumors. American Journal of Human Genetics 63 1544-1549.
Thakker RV 2006 Endocrine tumor syndromes. In Endocrinology, 5 edn , pp 3509-3531. Eds LJ DeGroot \& JL Jameson. Philadelphia: Elsevier Saunders.

Theiler K 1989 The House Mouse: Atlas of Embryonic Development. New York: Springer-Verlag.

Turner JJ, Leotlela PD, Pannett AA, Forbes SA, Bassett JH, Harding B, Christie PT, Bowen-Jones D, Ellard S, Hattersley A et al. 2002 Frequent occurrence of an intron 4 mutation in multiple endocrine neoplasia type 1. Journal of Clinical Endocrinology and Metabolism 87 2688-2693.

Wang P, Bowl MR, Bender S, Peng J, Farber L, Chen J, Ali A, Zhang Z, Alberts AS, Thakker RV et al. 2008 Parafibromin, a component of the human PAF complex, regulates growth factors and is required for embryonic development and survival in adult mice. Molecular and Cellular Biology 28 2930-2940.

Warner J, Epstein M, Sweet A, Singh D, Burgess J, Stranks S, Hill P, Perry-Keene D, Learoyd D, Robinson B et al. 2004 Genetic testing in familial isolated hyperparathyroidism: unexpected results and their implications. Journal of Medical Genetics 41 155-160.

Yao TP, Oh SP, Fuchs M, Zhou ND, Ch'ng LE, Newsome D, Bronson RT, Li E, Livingston DM \& Eckner R 1998 Gene dosage-dependent embryonic development and proliferation defects in mice lacking the transcriptional integrator p300. Cell 93 361-372.

Zhao Q, Behringer RR \& de Crombrugghe B 1996 Prenatal folic acid treatment suppresses acrania and meroanencephaly in mice mutant for the Cart1 homeobox gene. Nature Genetics 13 275-283.

Received in final form 9 June 2009

Accepted 7 July 2009

Made available online as an Accepted Preprint

8 July 2009 